\title{
The effects of initial spacing on growth and crown development for planted northern conifers: 37-year results
}

\author{
by K.M. McClain ${ }^{1}$, D.M. Morris ${ }^{2}$, S.C. Hills ${ }^{2}$, and L.J. Buse ${ }^{3}$
}

A spacing trial was established near Thunder Bay, Ontario in 1950. This trial consisted of black spruce (Picea mariana (Mill.) B.S.P.), white spruce (Picea glauca (Moench) Voss.), and red pine (Pinus resinosa Ait.) each established at three different spacings: $1.8 \mathrm{~m}, 2.7 \mathrm{~m}$, and $3.6 \mathrm{~m}$. This study examines the differences in growth and crown development as attributed to initial spacing, after 37 years. In addition, a benefit/cost analysis was performed to evaluate the economic efficiency of the various species/spacing combinations. Diameter at breast height, live crown length, and crown width, all exhibited significant $(\mathrm{P}<0.001)$ increases as initial spacing increased, irrespective of species, but, height demonstrated a decreasing trend $(\mathrm{P}<0.020)$. Gross total and merchantable stem volume per tree increased for all species as initial spacing increased; however, volume production per unit area decreased significantly for all species as spacing increased. The shift to higher-valued products from the wider-spaced plantations appeared to provide the best economic return. As a result of both greater merchantable volumes and greater percentages of these volumes available as a higher-valued product, benefit/cost ratios for red pine ( 0.995 to 1.337$)$ were greater than those for the spruces ( 0.595 to 0.866$)$. Although red pine currently represents less than $4 \%$ of Ontario's total regeneration effort, the results from this study suggest it deserves further consideration on some boreal sites.

Key words: spacing trial, plantation growth, crown development, black spruce, white spruce, red pine, benefit/cost ratio

\section{Introduction}

The forest industry contributes more to the balance of trade than all other commodities combined (Forestry Canada 1989). In Ontario a total of 214,000 ha of crown land was harvested in 1988 with a stumpage value of 77 million dollars (Ontario Ministry of Natural Resources 1990). In order to ensure economic viability of the industry, the provincial regeneration program was intensified in the mid-1970s with subsequent development of Forest Management Agreements which necessitated further expansion of stock production capability. Combined provincial and private seedling production reached a historical high of 172 million seedlings which were planted on 70,000 ha of crown land in 1989 (Ontario Ministry of Natural Resources 1990). Four conifer species (black spruce - Picea mariana (Mill.) B.S.P., jack pine - Pinus banksiana Lamb., white spruce - Picea glauca (Moench) Voss, and red pine - Pinus resinosa Ait.) represented 87 percent of the total.

Currently in northern Ontario, plantations are established at $2 \mathrm{~m}$ spacing (2,500 stems per ha). Wider spacings are being advo-

\footnotetext{
${ }^{1}$ Present Address: Forestry Canada, Prince George District Office, RR\#8, Site 25, Comp. 10, Prince George, British Columbia, Canada V2N 4M6.

${ }^{2}$ Ontario Forest Research Institute, Centre for Northern Forest Ecosystem Research, c/o Lakehead University, 955 Oliver Road, Thunder Bay, Ontario, Canada P7B 5E1.

${ }^{3}$ Ontario Ministry of Natural Resources, Ontario Forest Research Institute, P.O. Box 969, Sault Ste. Marie, Ontario, Canada P6A 5N5.
}

Une plantation a été réalisé à titre expérimental près de Thunder Bay en Ontario en 1950. Cet essai portait sur l'épinette noire (Picea mariana (Mill.) B.S.P.), l'épinette blanche (Picea glauca (Moench) Voss.), et le pin rouge (Pinus resinosa Ait.) chacune des espèces plantée selon trois espacements: $1.8 \mathrm{~m}, 2.7 \mathrm{~m}$, et $3.6 \mathrm{~m}$. Cette étude se penche sur les différences en croissance et en développement de la cime en fonction de l'espacement initial, 37 ans plus tard. De plus, une analyse des bénéfices en fonction des coûts a été effectuée afin d'évaluer l'efficacité économique de différentes combinaisons d'espèces et d'espacement. Le diamètre à hauteur de poitrine, la longueur de la cime vivante et le diamètre de la cime ont tous démontré des augmentations significatives $(P<0.001)$ en fonction de l'augmentation de l'espacement initial, pour toutes les espèces, mais la hauteur suivait une tendance inverse $(P<0.020)$. Le volume total et le volume marchand par arbre a augmenté pour toutes les espèces à mesure que s'accroissait l'espacement initial, alors que le volume par unité de surface diminuait significativement pour toutes les espèces en fonction de l'augmentation de l'espacement. Le changement vers des produits de plus grande valeur tirés des plantations à espacement plus grand semble procurer le meilleur retour sur l'investissement. Les résultats à la fois au niveau des volumes marchands supérieurs et du plus fort pourcentage de ces volumes disponibles en tant que produit de valeur supérieure ont permis d'obtenir des ratios des bénéfices en fonction des coûts pour le pin rouge $(0.995$ à 1.337$)$ plus élevés que ceux des épinettes $(0.595$ à 0.866 ). Même si le pin rouge ne représente actuellement que moins de $4 \%$ de l'effort total de régénération en Ontario, les résultats de cette études démontrent qu'il mérite de plus amples considérations sur certains sites de la forêt boréale. cated by some to reduce establishment costs and produce larger individual trees, which in turn should reduce harvesting costs and provide a wider array of products (Willcocks et al. 1990, Bell et al. 1990). This recommendation is largely based on the generalization that total volume production by a stand of a given age and composition on a given site is constant and optimum for a wide range of densities (Smith 1962). As early as the $1800 \mathrm{~s}$, it was realized that the spacing at which trees are grown has a significant effect on the productivity of the individual tree, the productivity of the stand as a whole, and the quality of wood produced. This relationship offers forest managers an opportunity to make a major impact on individual tree size, stand yield, future products, and production costs via stand density manipulations (Drew and Flewelling 1979). But what initial stand densities and rates of thinning (self-thinning or mechanical) are appropriate for different stand management objectives?

It is generally accepted that for a given site, the gross total volume is unaffected over a wide range of densities (Harper 1977; Mohler et al. 1978; Drew and Flewelling 1977; Bell et al. 1990). After crown closure, stands self-thin along a maximum sizedensity line and this line has been given a variety of names. For example, Drew and Flewelling (1979) call it the upper limit of the zone of imminent competition-mortality; Smith (1989) refers to it as the size-density asymptote. This relationship has been recognized as the $3 / 2$ self-thinning rule (Yoda et al. 1963). Utilizing this size-density theory, stand density management diagrams 
have been developed for a variety of species, such as: Pinus radiata D. Don (Drew and Flewelling 1977), Pseudotsuga menziesii (Mirb.) Franco (Drew and Flewelling 1979; Puettmann et al. 1993), Alnus rubra Bong. (Smith and Hann 1984, 1986; Puettmann et al. 1993), Pinus resinosa Ait. (Smith and Hann 1984, 1986; Smith and Brand 1988), Pinus contorta Dougl. (McCarter and Long 1986), Thuja plicata Donn ex D. Don (Smith 1989), Pinus elliottii Engelm. var. elliottii (Dean and Jokela 1992). These diagrams represent graphically the relationship between volume, quadratic diameter, dominant height, and stand density (stems per unit area) and allow forest managers to devise alternative density-management regimes to meet certain objectives while developing crop plans (Day 1985).

Although these stand density diagrams illustrate that wider initial spacing improves survival (Zavitkovski and Dawson 1977) and enhances diameter and stem volume growth (Stiell and Berry 1973a, b; Bella and DeFranceschi 1974, 1980; Zavitkovski and Dawson 1977), they do not adequately address other form-related components such as stem shape (Morris and Parker 1992), branchiness (Janas and Brand 1988), and wood quality (Zobel and van Buijtenen 1989). It has been hypothesized that other component parts may have their own characteristic size-density trajectories and maximum size-density lines (Mohler $\mathrm{et} \mathrm{al}$. 1978, Smith 1986).

Although a great deal of information is available in support of the thinning theory and it has been used to detail the growth and development of plantations in several forest regions, little is known about plantation growth and development in the boreal forest. In the past, wood extraction was primarily from natural stands and therefore growth and yield prediction models (Plonski 1956; Wiltshire 1982; Lenthall 1986) were based on data obtained from these stands. However, most natural stands in this forest region are of fire-origin, established at extremely high initial densities, and subsequently progress through long periods of self-thinning (Yarranton and Yarranton 1975; Carleton and Wannamaker 1987; Kenkel 1988). Boreal plantations are generally established at relatively lower initial densities and therefore would be expected to have different growth and development patterns than their natural counterparts. In the future, forest operations will need to shift their focus onto these plantations to meet the growing demand for wood fibre. This will require accurate yield prediction models for these stand types. Therefore the purpose of this study was to examine the influence of initial spacings on the growth and crown development of boreal plantations and demonstrate how these patterns relate to self-thinning theory. This information is intended to provide useful data for the development of growth and yield models for boreal plantations.

\section{Materials and Methods \\ Site Description}

In 1950, the Research Branch of the Ontario Ministry of Natural Resources, then the Department of Lands and Forests, established an 8 ha spacing trial southwest of Thunder Bay, Ontario $\left(48^{\circ} 22^{\prime} \mathrm{N}, 89^{\circ} 23^{\prime} \mathrm{W}\right)$. This trial contained plantings of three species (black spruce - Picea mariana (Mill.) B.S.P., white spruce - Picea glauca (Moench) Voss, and red pine - Pinus resinosa Ait.) established at three initial spacings $(1.8 \mathrm{~m}, 2.7 \mathrm{~m}$, and $3.6 \mathrm{~m})$. The trial was on a glaciolacustrine plain with gently rolling topography. Soil textures were fine sandy loams over sandy clay loam at depth greater than $160 \mathrm{~cm}$. Soil moisture regime was fresh and drainage rapid, except in localized areas where drainage was impeded due to the broken development of a clay loam lens (at varying depths but generally greater than $80 \mathrm{~cm}$ ). The estimated site index (mean dominant height at age 50) for black and white spruce was $18 \mathrm{~m}$ and $21 \mathrm{~m}$ for red pine (Thrower 1986). The site was used for agricultural purposes prior to the establishment of the spacing trial.

\section{Trial Establishment}

The designated planting area was prepared by ploughing and was immediately planted in the bottom of the furrows with $2+2$ bed-run stock of local seed origin in the fall of 1950. Additional seedlings were planted on site and transplanted as required to replace early mortality that occurred during the subsequent first two years. Three replications for each of the three species (black spruce, white spruce, and red pine) per spacing regime $(1.8 \mathrm{~m}$, $2.7 \mathrm{~m}, 3.6 \mathrm{~m}$ ) were included in the trial ( 27 plots in total). Number of seedlings per plot (approximately $1,300 \mathrm{~m}^{2}$ ) varied depending on the spacing with 414,180 , and 108 seedlings being planted for the $1.8 \mathrm{~m}, 2.7 \mathrm{~m}$, and $3.6 \mathrm{~m}$, respectively. The design of the trial is presented in Figure 1. The empty plots were originally planted with white pine (Pinus stobus L.) but were removed in 1965 due to severe damage caused by white pine weevil (Pissodes strobi (Peck)) and white pine blister rust (Cronartium ribicola Fischer). Only one of the $1.8 \mathrm{~m}$ plots of black spruce remains. One was destroyed by a root rot infection and replanted to red pine in 1956, whereas the other plot was planted to white spruce, by mistake, during establishment of the trial (Figure 1). Since establishment, no management (e.g. weeding, thinning, pruning) other than protection was applied to alter growth and development.

\section{Assessments and Analysis}

Outside bark DBH (100\% sample), total height (10\% sample - weighted according to diameter distribution), and crown length and width (same trees used for total height) were tallied in 1967 (age 16), 1976 (age 25), 1983 (age 32), and 1988 (age 37). The outside row was used as a buffer and therefore was not measured. Using total height and DBH for the $10 \%$ sam$\mathrm{ple}$, gross total stem volumes/tree and /ha were calculated using Forslund's (1991) equation ([7]). Merchantable volumes were estimated using Waint's et al. (1991) equations ([2] and [3]). In addition, a $100 \%$ sample of survival was conducted in 1967, 1983, and 1988.

Using 1988 data, one-way ANOVAs were completed using each of the measured variables to determine the effect of initial spacing on growth and crown development of the three species. Student-Newman-Keuls multiple range test was used as the means separation test for the main effect (spacing).

Since simple volume production is not always the best measure of plantation efficiency, a benefit/cost analysis was conducted for the 37-year-old plantations. This measure is the quotient of the mill gate cost (discounted initial establishment cost, harvest, transport, and re-establishment costs) of one ha of plantation at the different spacings and the potential revenue generated from the merchantable volume produced after 37 growing seasons obtained from this ha of land. A real discount rate of $4 \%$ was used in the analysis based on historical standards (Willcocks et al. 1990). Site preparation costs were taken from Willcocks et al. (1990) and held constant for all spacings at $\$ 254.73 \mathrm{ha}^{-1}$. Planting costs for the different spacings were 


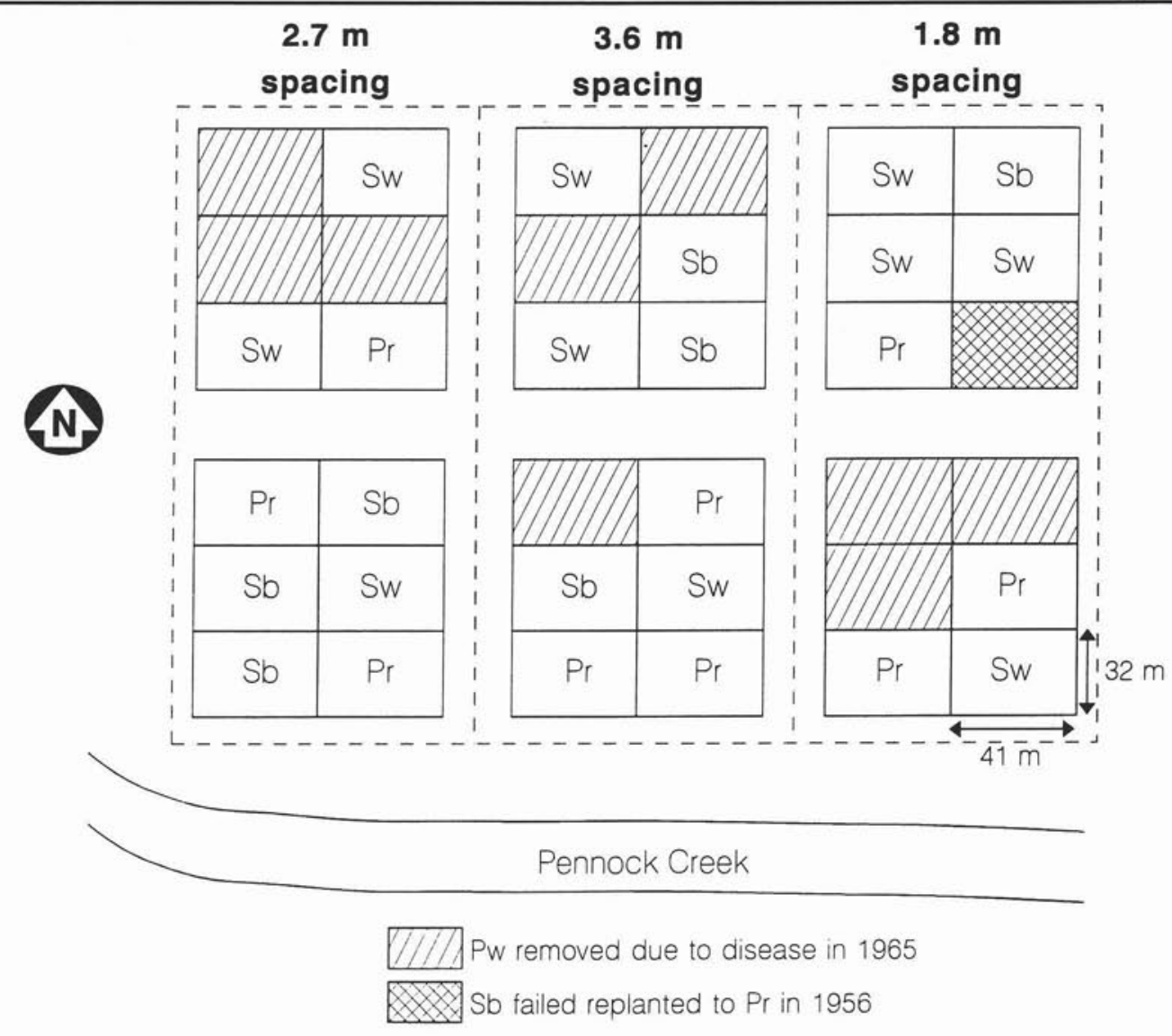

Figure 1. Plot layout for spacing trial established in 1950.

taken as the product of the number of trees planted $\mathrm{ha}^{-1}$ and the average cost of planting bare root stock of $\$ 0.35$ per seedling (Willcocks et al. 1990). Total harvesting costs were comprised of felling, skidding, delimbing, slashing, loading, and overhead costs and were subdivided into spruce $\left(\$ 18.40 / \mathrm{m}^{3}\right)$ and pine $\left(\$ 16.40 / \mathrm{m}^{3}\right)$ working groups based on operability differences. A transportation cost of $\$ 4.60 / \mathrm{m}^{3}$, based on a mill distance of $30 \mathrm{~km}$, was also included in the analysis. To calculate potential revenues, total merchantable volume was divided into both sawlog (minimum DBH $-22 \mathrm{~cm}$ ) and pulpwood (minimum $\mathrm{DBH}-8 \mathrm{~cm}$ ) products with associated mill gate prices of $\$ 39.73 / \mathrm{m}^{3}$ and $\$ 36.19 / \mathrm{m}^{3}$, respectively. Both the harvesting costs and mill gate prices were obtained from local forest operators.

\section{Results and Discussion}

Establishment and growth of vegetation are influenced by available growing space. With increased space, the growth of vegetation increases to a maximum governed by the capability of the plant and availability of site resources. Decisions on spacing at time of planting affect the long-term growth and development of plantations. Means and standard deviations (Table 1) for the four morphological parameters are presented, as well as the live crown ratio, density, survival, and calculated gross and merchantable stem volumes (per tree and per ha) for the data collected in 1988 (year 37). The data collected for the earlier sample years are presented (Figure 2) and used to illustrate the volume-density trajectories for the three species over the range of initial densities. Using crown width and initial spacing as a crude measure of crown closure, closure has occurred for all species/spacing combinations (Table 1: crown width $\geq$ initial spacing). Based on these ratios, the plantations established at $2.7 \mathrm{~m}$ and $3.6 \mathrm{~m}$ spacing are between crown closure and the lower limit of the imminent competition-mortality line (self-thinning zone). During this period, stands experience their greatest growth rates (Smith and Hann 1986), and this is illustrated by near-vertical volume-density trajectory lines (Figure 2). In contrast, the plantations established at $1.8 \mathrm{~m}$ spacing appear to have entered the zone of imminent competition-mortality. Growth rates for these plantations have slowed and the plantations have begun to self-thin (survival below $90 \%$ - Table 1). This relationship is illustrated by curvilinear volume-density trajectory lines. The slope of the volume-density trajectory lines for the wider spaced plantations $(2.7 \mathrm{~m}$ and $3.6 \mathrm{~m}$ ) will likely begin to conform to that of the closest spacing once the plantations reach the zone of imminent competition-mortality (Drew and Flewelling 1979; Smith and Hann 1986). As these plantations continue to age, self-thinning is expected to intensify and the volume-density trajectories for all species/spacing combinations should approach and run parallel to the upper asymptote. Verification of this trend is awaiting future measurements. 
Table 1. Stem growth and crown characteristics of 37-year-old black spruce, white spruce, and red pine plantations established at three different spacings

\begin{tabular}{|c|c|c|c|c|c|c|c|c|c|c|c|}
\hline \multirow[b]{2}{*}{$\begin{array}{l}\text { Spacing } \\
\text { (m) }\end{array}$} & \multirow[b]{2}{*}{$\begin{array}{l}\text { Height } \\
\text { (m) }\end{array}$} & \multirow[b]{2}{*}{$\begin{array}{l}\text { DBH } \\
(\mathbf{c m})\end{array}$} & \multirow[b]{2}{*}{$\begin{array}{c}\text { Crown } \\
\text { width } \\
\text { (m) }\end{array}$} & \multirow[b]{2}{*}{$\begin{array}{l}\text { Crown } \\
\text { length } \\
\text { (m) }\end{array}$} & \multirow[b]{2}{*}{$\begin{array}{l}\text { Live Crown } \\
\text { ratio } \\
\text { (m) }\end{array}$} & \multirow[b]{2}{*}{ 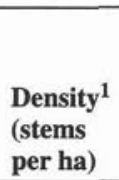 } & \multirow[b]{2}{*}{$\begin{array}{c}\text { Survival } \\
(\%)\end{array}$} & \multicolumn{2}{|c|}{$\begin{array}{c}\begin{array}{c}\text { Gross total } \\
\text { stem volume }\end{array} \\
\end{array}$} & \multicolumn{2}{|c|}{$\begin{array}{c}\text { Merchantable } \\
\text { stem volume }\end{array}$} \\
\hline & & & & & & & & $\begin{array}{l}\text { per } \\
\text { tree } \\
\left(\mathrm{dm}^{3}\right)\end{array}$ & $\begin{array}{r}\text { per } \\
\text { ha } \\
\left(\mathrm{m}^{3}\right)\end{array}$ & $\begin{array}{l}\text { per } \\
\text { tree } \\
\left(\mathbf{d m}^{3}\right)\end{array}$ & $\begin{array}{r}\text { per } \\
\text { ha } \\
\left(\mathrm{m}^{3}\right)\end{array}$ \\
\hline \multicolumn{12}{|c|}{ Black spruce } \\
\hline 1.8 & $\begin{array}{l}11.8 \\
(1.54)^{3}\end{array}$ & $\begin{array}{l}14.3 \\
(3.42)\end{array}$ & $\begin{array}{l}2.2 \\
(0.30)\end{array}$ & $\begin{array}{l}5.2 \\
(1.34)\end{array}$ & $\begin{array}{l}44.22 \\
(9.56)\end{array}$ & 2632 & 85.3 & $\begin{array}{c}107.2 \\
(48.60)\end{array}$ & 282.1 & 86.6 & 217.5 \\
\hline 2.7 & $\begin{array}{l}11.6 \\
(0.99)\end{array}$ & $\begin{array}{l}16.2 \\
(3.20)\end{array}$ & $\begin{array}{l}2.7 \\
(0.45)\end{array}$ & $\begin{array}{l}6.6 \\
(0.87)\end{array}$ & $\begin{array}{l}57.15 \\
(4.59)\end{array}$ & 1266 & 92.3 & $\begin{array}{c}128.0 \\
(50.15)\end{array}$ & 162.1 & 111.0 & 138.5 \\
\hline 3.6 & $\begin{array}{l}10.9 \\
(1.06)\end{array}$ & $\begin{array}{l}17.8 \\
(3.24)\end{array}$ & $\begin{array}{l}3.7 \\
(0.42)\end{array}$ & $\begin{array}{l}8.7 \\
(1.07)\end{array}$ & $\begin{array}{l}80.03 \\
(5.93)\end{array}$ & 714 & 92.5 & $\begin{array}{c}144.8 \\
(54.94)\end{array}$ & 103.4 & 130.9 & 92.9 \\
\hline \multicolumn{12}{|c|}{ White spruce } \\
\hline 1.8 & $\begin{array}{l}11.8 \\
(1.90)\end{array}$ & $\begin{array}{l}14.6 \\
(4.75)\end{array}$ & $\begin{array}{l}2.1 \\
(0.54)\end{array}$ & $\begin{array}{l}4.6 \\
(1.50)\end{array}$ & $\begin{array}{l}38.08 \\
(8.69)\end{array}$ & 2554 & 82.8 & $\begin{array}{c}129.2 \\
(82.90)\end{array}$ & 330.7 & 109.9 & 255.4 \\
\hline 2.7 & $\begin{array}{l}11.8 \\
(1.73)\end{array}$ & $\begin{array}{l}18.4 \\
(5.49)\end{array}$ & $\begin{array}{l}2.7 \\
(0.53)\end{array}$ & $\begin{array}{l}6.5 \\
(1.42)\end{array}$ & $\begin{array}{l}55.20 \\
(8.06)\end{array}$ & 1162 & 84.7 & $\begin{array}{c}179.2 \\
(94.88)\end{array}$ & 208.3 & 164.6 & 181.8 \\
\hline 3.6 & $\begin{array}{l}10.9 \\
(1.47)\end{array}$ & $\begin{array}{l}21.5 \\
(5.40)\end{array}$ & $\begin{array}{l}3.7 \\
(0.50)\end{array}$ & $\begin{array}{l}7.8 \\
(1.51)\end{array}$ & $\begin{array}{l}71.07 \\
(8.48)\end{array}$ & 711 & 92.1 & $\begin{array}{c}209.4 \\
(84.97)\end{array}$ & 148.9 & 198.7 & 138.1 \\
\hline \multicolumn{12}{|l|}{ Red pine } \\
\hline 1.8 & $\begin{array}{l}16.1 \\
(0.85)\end{array}$ & $\begin{array}{l}18.4 \\
(4.18)\end{array}$ & $\begin{array}{l}2.1 \\
(0.46)\end{array}$ & $\begin{array}{l}4.8 \\
(0.89)\end{array}$ & $\begin{array}{l}29.74 \\
(4.98)\end{array}$ & 2763 & 89.5 & $\begin{array}{c}199.8 \\
(67.47)\end{array}$ & 552.0 & 177.6 & 490.7 \\
\hline 2.7 & $\begin{array}{l}16.5 \\
(0.64)\end{array}$ & $\begin{array}{l}24.6 \\
(3.89)\end{array}$ & $\begin{array}{l}3.0 \\
(0.38)\end{array}$ & $\begin{array}{l}6.4 \\
(0.74)\end{array}$ & $\begin{array}{l}38.74 \\
(4.01)\end{array}$ & 1240 & 90.4 & $\begin{array}{c}358.7 \\
(76.60)\end{array}$ & 448.8 & 344.6 & 424.9 \\
\hline 3.6 & $\begin{array}{l}15.6 \\
(0.65)\end{array}$ & $\begin{array}{l}28.9 \\
(3.21)\end{array}$ & $\begin{array}{l}4.0 \\
(0.56)\end{array}$ & $\begin{array}{l}7.1 \\
(0.57)\end{array}$ & $\begin{array}{l}45.65 \\
(3.71)\end{array}$ & 725 & 93.9 & $\begin{array}{c}474.5 \\
(62.77)\end{array}$ & 344.0 & 464.3 & 336.6 \\
\hline
\end{tabular}

${ }^{1}$ Initial densities were 3086,1372 , and 772 stems/ha for the $1.8 \mathrm{~m}, 2.7 \mathrm{~m}$, and $3.6 \mathrm{~m}$ spacings, respectively.

${ }^{2}$ Merchantable volumes were estimated using equations [2] and [3] outlined by Wiant et al. (1991). In addition, an operability lower limit of $8 \mathrm{~cm}$ DBH was used in estimating the merchantable volume per hectare.

${ }^{3}$ Values in parentheses represent standard deviations.

With wider spacing, DBH, crown length, and crown width exhibited increases, irrespective of species. Conversely, height demonstrated a decreasing trend as spacing increased. A similar downward trend was identified by Bella and DeFranceschi (1980) for jack pine, although they found no significant height differences attributable to spacing for 15 -year-old red pine. This reduction in height growth may be related to a shifting of resource allocations as relative sink strengths of the corresponding meristems change. The cambial sink relies exclusively on current photosynthate for growth (Lanner 1985), therefore, is influenced more by environmental conditions (including available growing space) than is the apical meristem. As more resources are available for individual trees in the wider spacings, the data suggest that a greater proportion of the resources are directed into radial stem growth and branch development.

Gross total stem volumes (Table 1) indicate that the closest spacing resulted in the largest volume production per ha for all species even though individual stem volumes were substantially smaller. However, not all of this stand productivity can be captured in a conventional timber harvest. The effect of initial spacing (Figure 3 ) on the diameter distributions of the developing stands of black spruce, white spruce, and red pine, respectively, aid in determining the proportion of stems within a given plantation which could be captured in a conventional harvest or are suitable for a given product. For example, if the minimum diameter for harvest is taken to be the $8 \mathrm{~cm}$ diameter class (pulp), then $88 \%$ of the living black spruce stems planted at 1.8 $\mathrm{m}$ spacing could be captured in a harvest at age 37 as opposed to 97 and $99 \%$ of the living stems within the $2.7 \mathrm{~m}$ and the $3.6 \mathrm{~m}$ spacings (Figure 3). Virtually $100 \%$ of the living stems for white spruce and red pine exceed this $8 \mathrm{~cm}$ diameter class at all spacings. These two species, however, are commonly grown for sawlog production which requires a greater minimum diameter $(22 \mathrm{~cm})$ for selection. Using this as a criteria, only $6 \%$ of the white spruce and $18 \%$ of the red pine stems grown at the $1.8 \mathrm{~m}$ spacing would be considered for sawlogs. This increases to $50 \%$ and $97 \%$ for white spruce and red pine, respectively, when established at $3.6 \mathrm{~m}$ spacing (Figure 3).

\section{Univariate Analysis of Variance}

Univariate ANOVA was performed on the basis of the three spacing regimes as well as incorporating a replication effect. The replication component in the analysis was highly significant ( $p<0.01$ ) in many cases (Table 2). Although the trial was established on a uniform site, the localized, broken development of a clay loam lens (W. Carmean, per. com.) with evidence of imperfect drainage (gleying) may account for some of the variation identified between replications within the various species/spacing treatments. More importantly, previous land use/treatment (e.g. fertilization during agricultural use) may have had an impact on growth.

The ANOVA results (Table 2) clearly indicate that a highly significant difference $(p<0.01)$ was present among spacing levels within each species for diameter, crown length, and crown width at age 37 . Increases in response to increased initial spacing in stem diameter and crown width were most pronounced in red pine ( $57.0 \%$ in diameter, $90.5 \%$ in crown width), followed by white spruce ( $47.3 \%$ in diameter, $76.2 \%$ in crown width), 

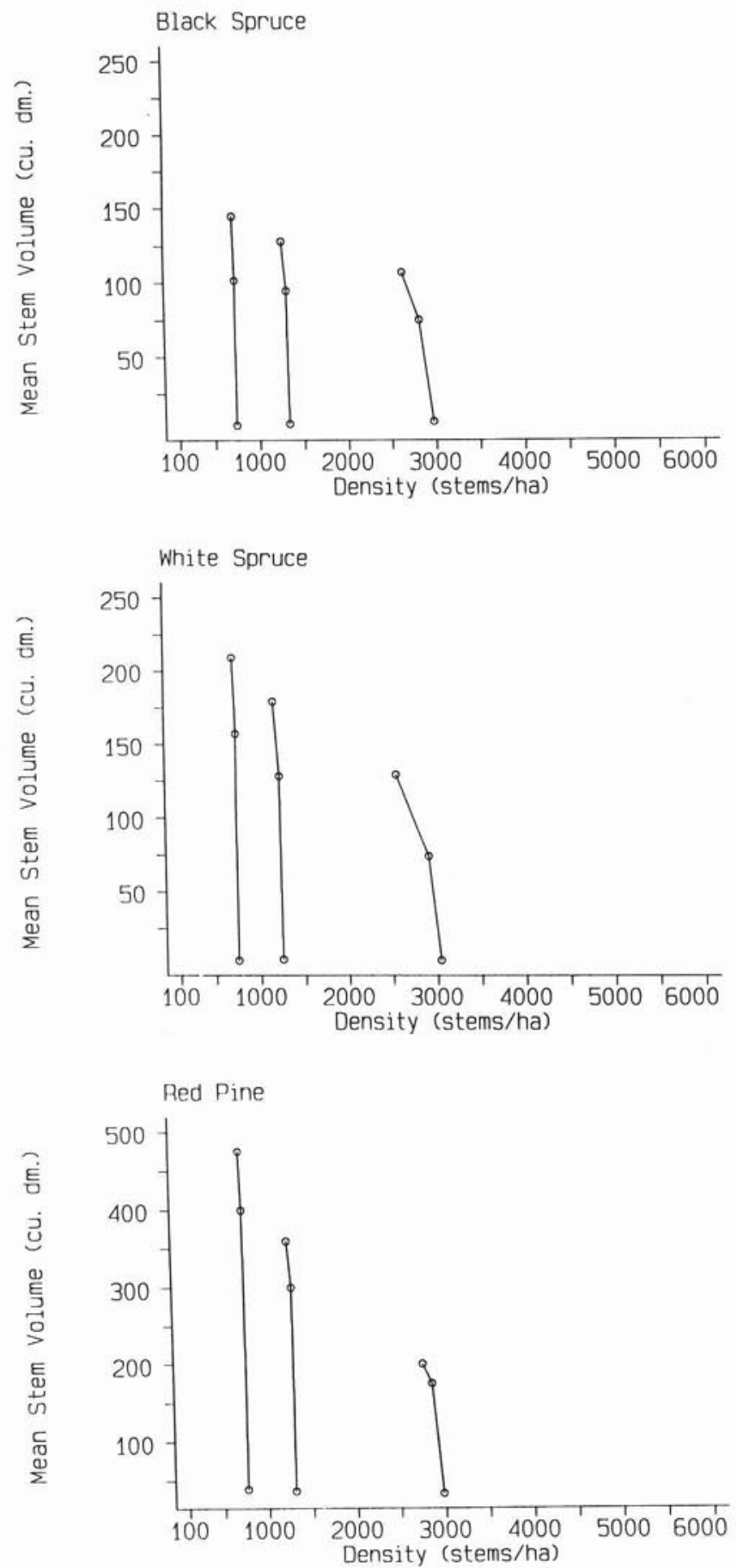

Figure 2. Relationship between stand density and stem volume yield, for 37-year-old black spruce, white spruce, and red pine plantations established at three different spacings.

and then black spruce ( $24.5 \%$ in diameter, $68.2 \%$ in crown width). In contrast, increases in crown length from high to low density were most pronounced in the spruces (white spruce - 69.6\%, black spruce, $-67.3 \%$, red pine $-47.9 \%$ ). These percent increases are simply the change in the given variable from high to low density expressed as a ratio of the numeric value obtained from the highest density. The results of the StudentNewman-Keuls means separation test verified these findings with few exceptions; increased spacing resulted in significant increases (Table 2).

Retention of lower branches at the wider spacings, depicted in greater live crown ratios, was most notable in the spruces where ratios over $70 \%$ were common. These large live crown ratios were in contrast to those for red pine whose living crowns rarely represented more than $45 \%$ of the total height at the widest spacing and as low as $30 \%$ at the closest spacing (Table 1). Although this intensive self-pruning exhibited by red pine has positive impacts in terms of wood quality (e.g. reduction in number and size of knots), these low live crown ratios do have possible implications for future management alternatives. For example, based on current individual and stand volumes for these 37-year-old plantations, there is a real potential to conduct a commercial thinning. The purpose of such a thinning would be two fold: 1) to provide an intermediate economic return prior to final harvest, and 2) to open up the stand for future enhanced growth of the remaining trees. However, Long (1985) states that a minimum live crown ratio of $40 \%$ is required for a prompt response to thinning. Based on this relationship, the spruce plantations would be good candidates (Table 1: mean live crown ratios ranging from $80 \%$ to $38 \%$ ). Enhanced growth in red pine, however, may be limited due to the lower mean live crown ratios (Table 1: $46 \%$ to $30 \%$ ).

As a result of the significant diameter increase combined with a marginal decrease in height, gross total stem volume per individual (mean tree) increased substantially for all species as spacing was increased (red pine $-137.5 \%$, white spruce $62.1 \%$, black spruce $-35.1 \%$ ). Somewhat greater increases were exhibited in merchantable stem volumes (red pine $-161.4 \%$, white spruce $-80.8 \%$, black spruce $-51.2 \%$ ). Although these increases are significant, by examining the influence of spacing on a volume production per unit area basis, a marked decrease in stem volume ha ${ }^{-1}$ did occur for all species as spacing increased. As indicated (Table 1), mortality was minimal in all spacing levels with self-thinning noticeable only in the $1.8 \mathrm{~m}$ spacing (Figure 2). However, if the volume-density generalization, commonly referred to as the $-3 / 2$ Power Law of Self-thinning (Yoda et al. 1963; Harper 1977) is correct, then volume ( $3 / \mathrm{ha}$ ) for all plantations should equalize over time with greater individual tree volumes for the wider spaced plantations.

\section{Management Implications}

This study focuses on growth rate differences and to a lesser extent, on form, as affected by stand density. Our results demonstrate how initial density has a direct influence on individual tree diameter and volume increment, as well as crown characteristics. The increase in crown length and width observed at lower densities implies that a decrease in wood quality may occur with respect to the occurrence of knots (both in number and size). Therefore, the forester is faced with a dilemma when selecting an initial spacing. Wide spacings produce large trees, but with reduced quality. Narrow initial spacings produce smaller trees, but with better form which, depending on product, may offset the economic loss incurred by producing smaller trees. Another option is to carry out a thinning on these narrower-spaced plantations. The effects of this type of silvicultural treatment are not well-documented in Ontario and the recommendation is based on two major assumptions: 1) remaining trees will respond to thinning with increased stem 

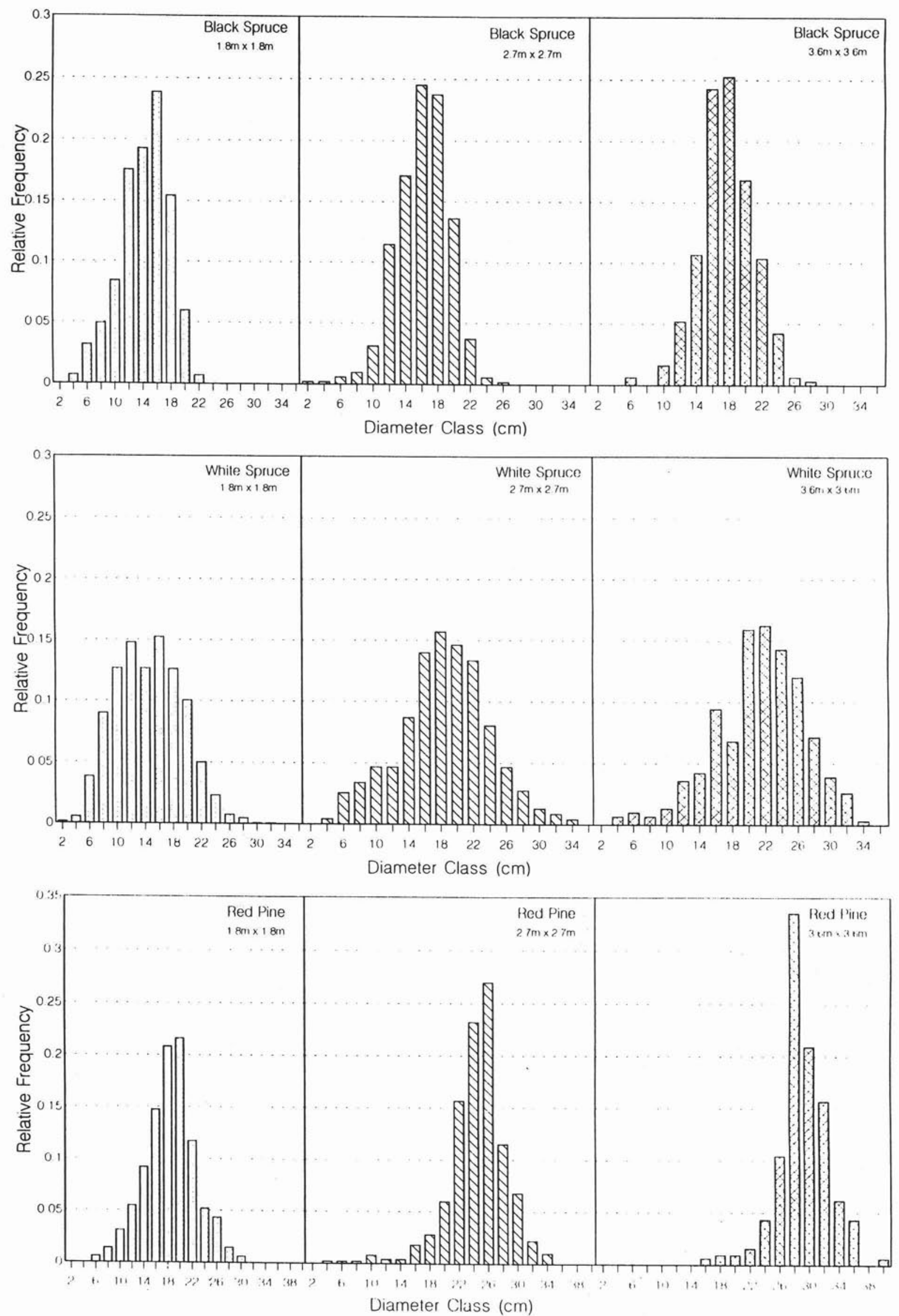

Figure 3. Diameter distribution for 37-year-old black spruce, white spruce, and red pine plantations established at three different initial spacings. 
Table 2. Summary of variance components and significance of initial spacing generated by one-way ANOVAs for stem growth and crown characteristics for black spruce, white spruce, and red pine 37 years after planting

\begin{tabular}{|c|c|c|c|c|c|c|}
\hline \multirow[b]{2}{*}{ Variable } & \multicolumn{5}{|c|}{ One-way ANOVA summaries } & \multirow{2}{*}{$\begin{array}{c}\text { Means } \\
\text { separation } 2 \\
\text { (Spacing) }\end{array}$} \\
\hline & MSRep & MSSpacing & MSError & $\begin{array}{c}F \text {-ratio }{ }^{1} \\
(\text { Rep) }\end{array}$ & $\begin{array}{c}F \text {-ratio } \\
\text { (Spacing) }\end{array}$ & \\
\hline \multicolumn{7}{|c|}{ Black spruce $(n=119)$ : } \\
\hline Height (m) & 4.44 & 5.93 & 1.35 & $\begin{array}{c}3.28 \\
\left(.041^{*}\right)\end{array}$ & $\begin{array}{r}4.38 \\
\left(.015^{*}\right)\end{array}$ & $1-23$ \\
\hline Diameter (cm) & 17.41 & 64.27 & 8.24 & $\begin{array}{r}2.11 \\
(.126)\end{array}$ & $\begin{array}{c}7.80 \\
\left(.001^{* *}\right)\end{array}$ & 321 \\
\hline Crown length & 16.32 & 83.96 & 1.12 & $\begin{array}{c}14.52 \\
\left(.001^{* *}\right)\end{array}$ & $\begin{array}{c}74.71 \\
\left(.000^{* *}\right)\end{array}$ & 321 \\
\hline Crown width (m) & 4.27 & 15.21 & 0.16 & $\begin{array}{c}26.88 \\
\left(.000^{* *}\right)\end{array}$ & $\begin{array}{c}95.63 \\
\left(.000^{* *}\right)\end{array}$ & 321 \\
\hline \multicolumn{7}{|c|}{ White spruce $(n=258)$ : } \\
\hline Height & 17.48 & 12.30 & 3.12 & $\begin{array}{c}5.60 \\
\left(.001^{* *}\right)\end{array}$ & $\begin{array}{r}3.94 \\
\left(.021^{*}\right)\end{array}$ & $1-23$ \\
\hline Diameter & 20.08 & 551.10 & 17.44 & $\begin{array}{r}1.15 \\
(.329)\end{array}$ & $\begin{array}{c}31.60 \\
\left(.000^{* *}\right)\end{array}$ & 321 \\
\hline Crown length & 33.74 & 144.02 & 2.17 & $\begin{array}{c}15.56 \\
\left(.000^{* *}\right)\end{array}$ & $\begin{array}{c}66.43 \\
\left(.000^{* *}\right)\end{array}$ & 321 \\
\hline Crown width & 3.92 & 33.42 & 0.28 & $\begin{array}{c}13.82 \\
\left(.000^{* *}\right)\end{array}$ & $\begin{array}{c}117.96 \\
\left(.000^{* *}\right)\end{array}$ & 321 \\
\hline \multicolumn{7}{|l|}{ Red pine $(n=251)$} \\
\hline Height & 11.72 & 8.82 & 0.45 & $\begin{array}{c}26.05 \\
\left(.000^{* *}\right)\end{array}$ & $\begin{array}{c}19.66 \\
\left(.000^{* *}\right)\end{array}$ & 213 \\
\hline Diameter & 99.67 & 1771.07 & 8.11 & $\begin{array}{c}12.29 \\
\left(.000^{* *}\right)\end{array}$ & $\begin{array}{c}218.28 \\
\left(.000^{* *}\right)\end{array}$ & 321 \\
\hline Crown length & 15.29 & 106.40 & 0.65 & $\begin{array}{c}23.52 \\
\left(.000^{* *}\right)\end{array}$ & $\begin{array}{c}164.22 \\
\left(.000^{* *}\right)\end{array}$ & 321 \\
\hline Crown width & 0.54 & 49.68 & 0.21 & $\begin{array}{r}2.59 \\
(.054) \\
\end{array}$ & $\begin{array}{c}241.27 \\
\left(.000^{* *}\right)\end{array}$ & 321 \\
\hline
\end{tabular}

${ }^{1}$ Values in parentheses represent probability levels (*denotes significance at $P<0.05$ and ** denotes significance at $P<0.01$ ).

${ }^{2}$ Results of SNK multiple range test following one-way ANOVA of spacing treatments $(1=1.8 \times 1.8 \mathrm{~m}, 2=2.7 \times 2.7 \mathrm{~m}, 3=3.6 \times 3.6 \mathrm{~m})$. Treatment units joined by a hyphen (e.g. 1-2) are not significantly different $(P<0.05)$ from each other.

Table 3. Summary of estimated costs and anticipated revenues for 37-year-old black spruce, white spruce, and red pine plantations established at three different spacings

\begin{tabular}{|c|c|c|c|c|c|c|c|c|c|}
\hline \multirow{3}{*}{$\begin{array}{l}\text { Spacing } \\
\text { (m) }\end{array}$} & \multicolumn{5}{|c|}{ Total estimated costs ${ }^{1}$} & \multirow{2}{*}{\multicolumn{3}{|c|}{ Total revenues ${ }^{2}$}} & \multirow{3}{*}{$\begin{array}{c}\text { Benefit/ } \\
\text { cost } \\
\text { ratio }\end{array}$} \\
\hline & \multirow{2}{*}{$\begin{array}{l}\text { Establishment } \\
\text { cost ( } 37 \text { yrs) }\end{array}$} & \multirow{2}{*}{$\begin{array}{c}\text { Harvest } \\
\text { cost }\end{array}$} & \multirow{2}{*}{$\begin{array}{l}\text { Transport } \\
\text { cost }\end{array}$} & \multirow{2}{*}{$\begin{array}{c}\text { Establishment } \\
\text { cost ( } 0 \text { yrs) }\end{array}$} & \multirow{2}{*}{$\begin{array}{l}\text { Total } \\
\text { cost }\end{array}$} & & & & \\
\hline & & & & & & Pulpwood & Sawlog & Total & \\
\hline & & & & (\$/ha) & & & & & \\
\hline \multicolumn{10}{|c|}{ Black spruce } \\
\hline 1.8 & $5,697.17$ & $5,190.64$ & $1,000.50$ & $1,334.83$ & $13,223.14$ & $7,871.33$ & 0.00 & $7,871.33$ & 0.595 \\
\hline 2.7 & $3,136.75$ & $2,982.64$ & 637.10 & 734.93 & $7,491.42$ & $4,615.40$ & 435.63 & $5,051.03$ & 0.674 \\
\hline 3.6 & $2,240.45$ & $1,902.56$ & 427.34 & 524.93 & $5,095.28$ & $2,762.41$ & 658.13 & $3,420.54$ & 0.671 \\
\hline \multicolumn{10}{|c|}{ White spruce } \\
\hline 1.8 & $5,697.17$ & $6,084.88$ & $1,174.84$ & $1,334.83$ & $14,291.72$ & $7,412.42$ & $2,009.06$ & $9,421.47$ & 0.659 \\
\hline 2.7 & $3,136.75$ & $3,832.72$ & 836.28 & 734.93 & $8,540.68$ & $3,384.23$ & $3,506.76$ & $6,891.00$ & 0.807 \\
\hline 3.6 & $2,240.45$ & $2,739.76$ & 635.26 & 524.93 & $6,140.40$ & $1,714.47$ & $3,603.63$ & $5,318.10$ & 0.866 \\
\hline \multicolumn{10}{|l|}{ Red pine } \\
\hline 1.8 & $5,697.17$ & $9,052.80$ & $2,257.22$ & $1,334.83$ & $18,342.02$ & $12,772.87$ & $5,471.86$ & $18,244.73$ & 0.995 \\
\hline 2.7 & $3,136.75$ & $7,360.32$ & $1,954.54$ & 734.93 & $13,186.54$ & $1,716.53$ & $14,993,07$ & $16,709.60$ & 1.267 \\
\hline 3.6 & $2,240.45$ & $5,641.60$ & $1,548.36$ & 524.93 & $9,955.34$ & 198.01 & $13,152.43$ & $13,350.44$ & 1.337 \\
\hline
\end{tabular}

${ }^{1}$ Total costs were estimated as follows: a) establishment cost ( 37 years) included site preparation ( $\left.\$ 254.73 / \mathrm{ha}\right)$ and planting ( $\$ 0.35 /$ tree $X$ no. of trees/ha) costs discounted (4\%) over 37 years; b) harvesting costs were calculated as operating costs (spruce $-\$ 18.40 / \mathrm{m}^{3}$, pine $\left.-\$ 16.40 / \mathrm{m} 3\right) \times$ gross total volume ( $\mathrm{m}^{3} / \mathrm{ha}$ ); c) transport cost were calculated as hauling costs $\left(\$ 4.60 / \mathrm{m}^{3}\right) \times$ merchantable volume $\left(\mathrm{m}^{3} / \mathrm{ha}\right)$; $\left.\mathrm{d}\right)$ establishment cost $(0$ years) was made up of site preparation and planting costs without adding a discounted value.

${ }^{2}$ Revenues were calculated using $\$ 36.19 / \mathrm{m}^{3} \times$ merchantable volume $\left(\mathrm{m}^{3} / \mathrm{ha}\right)$ of trees between $8.0-22.0 \mathrm{~cm}$ DBH for pulpwood and $\$ 39.73 / \mathrm{m}^{3} \times$ merchantable volume of trees greater than $22.0 \mathrm{~cm}$ DBH for sawlogs. 
volume growth and 2) the better form will continue through to rotation age after the thinning operation. These assumptions need to be verified. Many have argued that for pulp and paper manufacturing maximum volume is critical with little of no importance placed on wood quality. However, wood quality is also important in paper manufacturing as stem irregularities and associated compression wood, as well as the size and number of knots pose problems in debarking and chipping, require additional bleach agents, and can adversely affect pulp quality and yield (Timell 1986).

The effect of initial spacing and species selection on both total wood costs and anticipated revenues associated with growing and harvesting a 37-year-old plantation on a hectare of land, (Table 3) assumes that there is a local market for all pulpwood and sawlog material produced by all species. As initial spacing increased, volume production (Table1), total costs and revenues (Table 3) decreased for all species. However in terms of economic efficiency, as depicted in the benefit/cost ratios (Table 3), the wider-spaced plantations appear to provide the best economic return. These higher ratios, for the most part, are a result of a shift to a higher-value product (Figure 4). Since the black spruce plantations yield little sawlog material ( $0 \%$ at the narrowest spacing up to only $18 \%$ at the widest spacing), black spruce appears to exhibit an optimum spacing, in terms of benefit/cost ratio, between $1.8 \mathrm{~m}$ and $3.6 \mathrm{~m}$ spacings. Whether or not this optimum is maintained throughout the rotation remains to be determined. Benefit/cost ratios continued to increase as initial spacing was increased for both white spruce and red pine (Table 3 ) suggesting that even wider spacings may serve as optimal in terms of economic efficiency. The effect of species selection is also reflected in the difference in benefit/cost ratios. These differences are a result of both volume production differences, as well as the percentage of merchantable volume available as a higher valued product (Figure 4). In this case, red pine is out producing the two spruces in merchantable volume (Table1) with $28 \%$ ( $1.8 \mathrm{~m}$ spacing) to 98\% (3.6 m spacing) of this volume available as sawlog material. This combination results in a benefit/cost ratio ranging from 0.995 to 1.337 (Table 3).

Red pine represents a minor component of Ontario's total regeneration effort (3.5\% - Ontario Ministry of Natural Resources 1990) and would be even lower if based solely on northern Ontario, but the results of this study indicate that red pine clearly out performs both white and black spruce in terms of total volume production across the range of initial spacings and can achieve benefit/cost ratios greater than 1.000 after 37 years. Our total volumes per hectare are comparable to unthinned red pine plantations in Southern Ontario (Petawawa National Forestry Institute) established at similar spacings (Stiell and Berry 1973a). Their volumes on sites with $\mathrm{SI}_{50 \text { from }}$ planting $=24.4 \mathrm{~m}$ were $450.80 \mathrm{~m}^{3} / \mathrm{ha}(1.8 \mathrm{~m} \mathrm{spacing}), 392.35 \mathrm{~m}^{3} / \mathrm{ha}$ (2.7 m spacing), and $315.17 \mathrm{~m}^{3} / \mathrm{ha}$ (3.6 m spacing). Stiell and Berry (1973b) also reported on white spruce with total volumes of $240.68 \mathrm{~m} 3 / \mathrm{ha}(1.8 \mathrm{~m}$ spacing $)$ and $244.66 \mathrm{~m}^{3} / \mathrm{ha}(2.7$ $\mathrm{m}$ spacing) on sites with a $\mathrm{SI}_{50 \text { from planting }}=21.3 \mathrm{~m}$ which are slightly higher than our volumes. In southern pine plantations, Williston (1979) reported on intensively managed loblolly pine plantations and documented total stem volume yields of $328 \mathrm{~m}^{3} / \mathrm{ha}\left(\mathrm{SI}_{50}-24.4 \mathrm{~m}\right)$ and $435 \mathrm{~m}^{3} / \mathrm{ha}\left(\mathrm{SI}_{50}-27.4 \mathrm{~m}\right)$ at age 37 . These plantations were established at $1.8 \mathrm{~m}$ spacings and thinned, from below to $9.3 \mathrm{~m}^{2}$ of basal area, three times

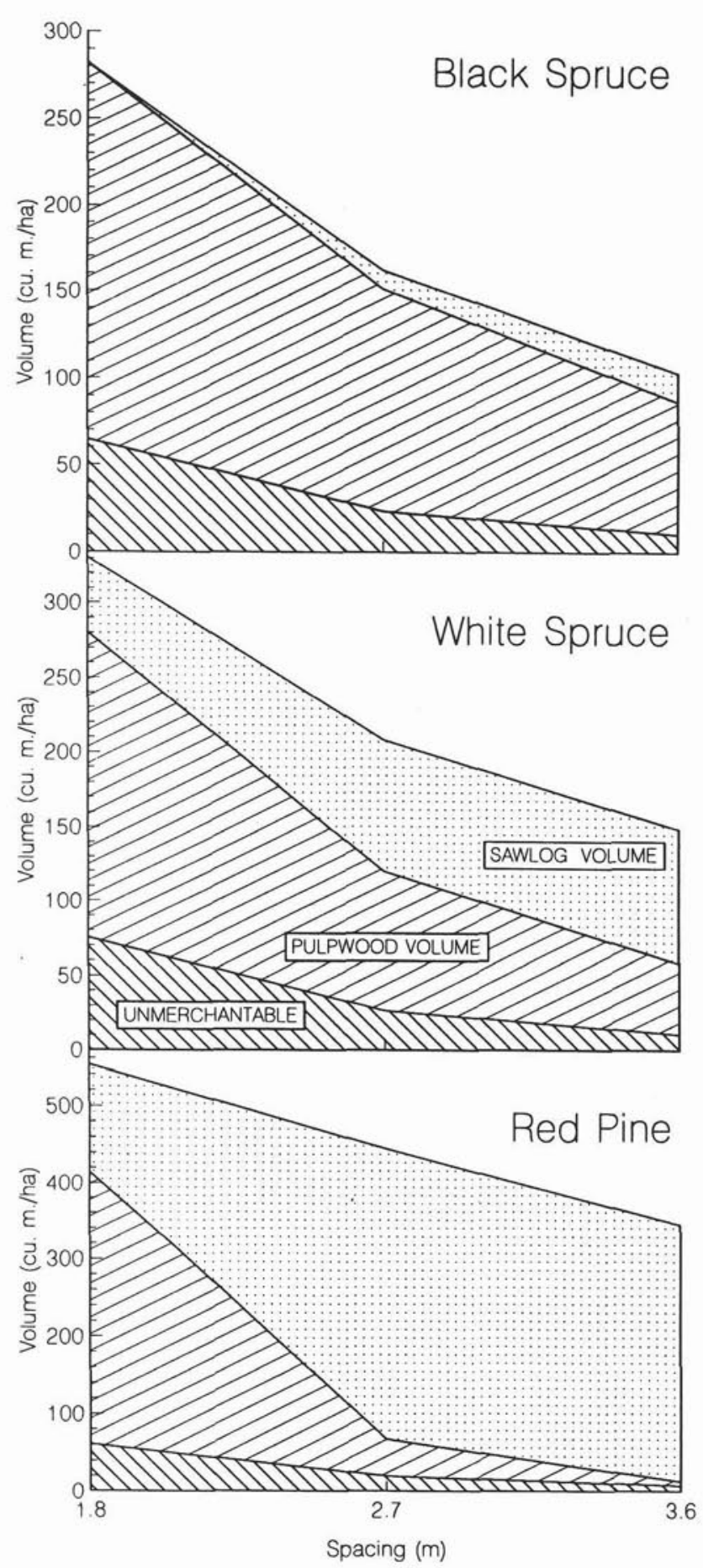

Figure 4. Relationship between initial spacing and merchantable product yield for 37-year-old black spruce, white spruce, and red pine plantations.

at five-year intervals starting at age 17 . The stem volumes removed by these thinnings were included in the total yields reported above. The red pine volumes produced in our trial compare favourably to those in Williston's (1979) study even though no management was applied to the Thunder Bay Spacing Trial. It follows, therefore, that with attentive management, the potential of red pine as an option in northern Ontario's regeneration strategy is worthy of consideration on highly productive sites. 


\section{Acknowledgements}

The authors extend their appreciation to A. Leslie (retired Research Director) and to N.F. Lyon (retired Research Scientist), for their foresight in designing and establishing the Thunder Bay Spacing Trial prior to the recognized need to understand basic growth and yield principles for boreal plantations. The 1988 data collection was completed by staff from the Northwestern Ontario Forest Technology Development Unit and funded under COFRDA (project \# 21013). The authors also appreciated the contribution made by $\mathrm{R}$. Collier on the initial economic analysis, as well as the thoughtful reviews of this manuscript provided by Dr. W. Carmean, R.J. Miller, J. Paterson, and two anonymous reviewers.

\section{References}

Bell, F.W., W.D. Baker and R. Vassov. 1990. Influence of initial spacing on jack pine wood yield and quality: A literature review. NWOFTDU Tech. Report \#10.

Bella, I.E. and J.P. DeFranceschi. 1974. Analysis of jack pine thinning experiments, Manitoba and Saskatchewan. Can. For. Serv., Publ. No. 1338.

Bella, J.E. and J.P. DeFranceschi. 1980. Spacing effects 15 years after planting three conifers in Manitoba. Can. For. Serv. No. F.R.C. Info. Rep. NOR-X-223.

Carleton, T.J. and B.A. Wannamaker. 1987. Mortality and self-thinning in postfire black spruce. Annals of Botany 59: 621-628.

Day, R.J. 1985. Crop plans in silviculture. Lakehead Univ., Sch. For. Rep. Reprinted by Can. Pulp. Pap. Assoc., W.S.I. 2975 (F-4) ODC 624.

Dean, T.J. and E.J. Jokela. 1992. A density-management diagram for slash pine plantations in the lower coastal plain. South. J. Appl. For. 16: 178-185.

Drew, T.J. and J.W. Flewelling. 1977. Some recent Japanese theories of yield density relationships and their application to Monterey pine plantations. For Sci. 23: 517-534.

Drew, T.J. and J.W. Flewelling. 1979. Stand density management: an alternative approach and its application to Douglas-fir plantations. For. Sci. 25: 518-532.

Forestry Canada. 1989. Selected forestry statistics Canada 1988. Forestry Canada, Economic and Statistics Directorate. Information Report E$\mathrm{X}-41$.

Forslund, R.R. 1991. The power function as a simple stem profile examination tool. Can. J. For. Res. 21: 193-198.

Harper, J.L. 1977. Population biology of plants. Academic Press, New York.

Janas, P.S. and D.G. Brand. 1988. Comparative growth and development of planted and natural stands of jack pine. For. Chron. 64: 320328.

Kenkel, N.C. 1988. Pattern of self-thinning in jack pine: testing the random mortality hypothesis. Ecology 69: 1017-1024.

Lanner, R.M. 1985. On the insensitivity of height growth to spacing. For. Ecol. Manage. 13: 143-148.

Lenthall, D.J. 1986. Height growth and site index of jack pine (Pinus banksiana Lamb.) in the Thunder Bay area: a system of site quality evaluation. M.Sc.F. thesis, Lakehead University, Thunder Bay, Ont.

Long, J.N. 1985. A practical approach to density management. For. Chron. 61: 23-27.

McCarter, J.B. and J.N. Long. 1986. A lodgepole pine density management diagram. West, J. Appl. For. 1: 6-11.
Mohler, C.L., P.L. Marks, and D.G. Sprugel. 1978. Stand structure and allometry of tree during self-thinning of pure stands. J. Ecol. 66: 599-614.

Morris, D.M. and W.H. Parker. 1992. Variable-quality form in mature jack pine stands: quantification and relationship with environmental factors. Can. J. For. Res. 22: 279-289.

Ontario Ministry of Natural Resources. 1990. Statistics 19881989. Queen's Printer for Ontario.

Plonski, W.L. 1956. Normal yield tables for black spruce, jack pine, aspen, and white birch in northern Ontario. Ont. Dept. of Lands and Forests. Timber Manage. Div. Rep. No. 24.

Puettmann, K.J., D.W. Hann, and D.E. Hibbs. 1993. Evaluation of the size-density relationships for pure red alder and Douglas-fir stands. For. Sci. 39: 7-27.

Smith, D.M. 1962. The practice of silviculture. John Wiley \& Sons, New York.

Smith, N.J. 1986. A model of stand allometry and biomass allocation during the self-thinning process. Can. J. For. Res. 16: 990-995. Smith, N.J. 1989. A stand-density control diagram for western red cedar, Thuja plicata. For. Ecol. Manage. 27: 235-244.

Smith, N.J. and D.G. Brand. 1988. Compatible growth models and stand density diagrams. In Proc. IUFRO Growth and Yield Conference, Minneapolis, MN.

Smith, N.J. and D.W. Hann. 1984. A new analytical model based on the $-3 / 2$ power rule of self-thinning. Can. J. For. Res. 14: 605-609. Smith, N.J. and D.W. Hann. 1986. A growth model based on the selfthinning rule. Can. J. For. Res. 16: 330-334.

Stiell, W.M. and A.B. Berry. 1973a. Yield of unthinned red pine plantations at the Petawawa Forest Experiment Station. Petawawa Forest Experiment Station, Dept. of Environ., Can. For. Serv. Publication No. 1320.

Stiell, W.M. and A.B. Berry. 1973b. Development of unthinned white spruce plantations to Age 50 at Petawawa Forest Experiment Station. Petawawa Forest Experiment Station, Dept. of Environ., Can. For. Serv. Publication No. 1317.

Timell, T.E. 1986. Compression wood in Gymnosperms. Vol. 2. SpringerVerlag, New York.

Thrower, J.S. 1986. Estimating site quality from early height growth of white spruce and red pine plantations in the Thunder Bay area. M.Sc.F. Thesis, School of Forestry, Lakehead University, Thunder Bay.

Wiant, H.V., Jr., G.B. Wood, and R.R. Forslund. 1991. Comparison of centroid and paracone estimates of tree volume. Can. J. For. Res. 21: 714-717.

Willcocks, A.J., F.W. Bell, J. Williams and P.N. Duinker. 1990. A crop-planning process for northern Ontario forests. NWOFTDU Tech. Report \#30.

Williston, H.L. 1979. Growth and yield to age 37 in North Mississippi loblolly plantations. South. J. Appl. For. 3: 127-130.

Wiltshire, W.B. 1982. Polymorphic site index curves for jack pine in the Thunder Bay Region. B.Sc.F. thesis, Lakehead University, Thunder Bay, Ont.

Yarranton, M. and G.A. Yarranton. 1975. Demography of a jack pine stand. Can. J. Bot. 53: 310-313.

Yoda, K., T. Kira, H. Ogawa, and K. Hozumi. 1963. Self-thinning in overcrowded pure stands under cultivated and natural conditions. J. Inst. Polytech. Osaka City Univ. Ser. D., 14: 107-129.

Zavitkovski, J. and D.H. Dawson. 1977. Structure and biomass production of 1- to 7-year-old intensively cultured jack pine plantations in Wisconsin. USDA For. Serv., North Cent. For. Exp. Sta., Res. Pap NC-157.

Zobel, B.J. and J.P. van Buijtenen. 1989. Wood variation: Its causes and controls. Springer-Verlag, New York. 